\title{
Training needs for women-owned SMEs in England
}

\section{Training needs for women- owned SMEs}

\author{
Centre for Women's Enterprise, University of Bedfordshire Business School, \\ University of Bedfordshire, Luton UK, and \\ Pegram Harrison \\ Emerging Leaders Programme, London Business School, London, UK
}

\begin{abstract}
Purpose - The purpose of this research is to investigate the needs and preferences for training among growth-oriented women-owned SMEs in the East of England.

Design/methodology/approach - Quantitative data were collected through 108 on-line questionnaires, and the means analysed using SPSS. Qualitative data collected in response to open-ended questions were inductively analysed and interpreted.

Findings - Only one fourth of respondents received growth-oriented training in the previous two years, with an average duration of 3-5 days per year. Programmes most in demand concerned innovation and opportunity recognition, business evaluation and growth considerations, developing strategic customers and customers care, customer relationship management, as well as selling, networking and negotiation skills. High demand for these programmes corresponds to others results identifying contributory factors to higher enterprise performance and growth: product/service quality, new product/service development, appropriate marketing, effective use of websites, selling skills and informal networking.

Research limitations/implications - The scope of the project is limited to service sectors and sole proprietorships. Geographic scope is limited to the East of England. These limits nonetheless provide a reasonable base and rationale for the scope of the study.

Practical implications - With a better understanding of the capacity building requirements of women entrepreneurs in growth businesses, appropriately designed training programmes can be developed to help women achieve higher levels of entrepreneurial success.

Originality/value - The study offers original primary research into the contributory growth factors for women-owned enterprises in a representative area of Britain, identifies key issues, maps survival and success factors, and assesses women entrepreneurs' training needs and preferences.
\end{abstract}

Keywords Women, Owner-managers, Training needs, Business development, Small to medium-sized enterprises, England

Paper type Research paper

This research study, conducted by the Centre for Women's Enterprise at the University of Bedfordshire, is supported by a grant from the Higher Education European Social Fund (HE-ESF). The authors are grateful to the following people for their assistance with this study: Dr John Beamount-Kerridge from the University of Bedfordshire for his technical help in online design and submission of the questionnaire; Sue Bathmaker, Dawn Jordan, Julie Tysoe, and Beatriz Acevedo from the Centre for Women's Enterprise, and Bev Hurley of YTKO, for editing the first draft of the questionnaire; Dawn Jordan and Julie Tysoe for soliciting input from the Centre for Women's Enterprise members, and Bev Hurley for promoting the questionnaire via Enterprising-Women's website and newsletter.

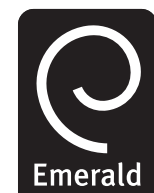

Education + Training Vol. 50 No. 8/9, 2008 pp. $687-696$ 0040-0912 
ET

$50,8 / 9$

688

\section{Introduction}

This study is part of primary research conducted to analyse factors affecting or contributing to the growth of women-owned enterprises in the East of England. The work seeks to identify not only the issues affecting the growth of women-owned enterprises in the region - by mapping factors contributing to their survival and success - but also to assess their training needs and preferences.

\section{Theoretical framework}

There is a general consensus that growth in enterprises is a complex process, which is neither linearly continuous nor dependent upon a specific set of factors (Deakins, 1996). Smallbone et al. (1995) confirm the complexity of the growth process by specifying a number of triggers to growth that in turn can consist of a number of causal factors.

Park and Bae (2004) confirm that "management ability" is one of the most influential factors in the successful growth of new ventures. This can be achieved either through experience or training, both on the job and in the classroom. For women entrepreneurs, lack of access to training and advisory services is one of the main reasons often used to explain under-performance (Brown et al., 2002; Brush and Hisrich, 1999). Heilbrunn (2004) also points out that most women-owned businesses show slow or no growth due to lack of business and managerial skills.

The literature separates factors thought to influence small business growth into two categories. The first comprises entrepreneurs' characteristics such as behaviour, personality, attitude (Storey, 1994); their capabilities, including education and training that create higher expectations in some industry sectors (Henry et al., 2005); and their social capital influencing access to resources (Brush et al., 2004). Other entrepreneurial factors identified by Storey (1994) are previous management experience, family history, functional skills, and relevant business sector knowledge. None of these, though, has been shown conclusively to constitute a universal success factor. The second category of the factors influencing business growth concerns the structure and goals of the business itself, and the performance of its management: in particular, an ability to make rational decisions about operations (Bridge et al., 1998).

There is an extensive basis in theory and growing empirical evidence that through training and capacity building (in both entrepreneurial characteristics and business structures) an owner-manger or entrepreneur can develop entrepreneurial competences (Brown et al., 2002, Brush and Hisrich, 1999). Moreover, Bridge et al. (1998) describe the importance of technical and management skills in adapting to and coping with changing environments, and identify such learned skills as key determining factors for growth.

Gorman et al. (1997, p. 56) acknowledge that the learning needs of entrepreneurs vary at different stages of development and in different cultural settings; their "underlying assumption for using audience segmentation [is] that educational objectives, subject matter and pedagogical approach might be expected to vary depending on the nature of the target audience". Others, including (Bridge et al., 1998; McMullan and Long, 1987; O'Gorman, 1997; van der Sijde et al., 1997) have more specifically identified that the training needs of an individual entrepreneur will vary according to the particular stage of venture development: idea, pre-start-up, start-up, growth, maturity. "Guided preparation", unless it is of a sort appropriate to the growth stage of a new venture, can even be counterproductive (Chrisman et al., 2005). Most 
specifically, Singh and Vinnicombe (2003) and Brush and Hisrich (2002) have established that, gender, too, has an impact upon the nature of entrepreneurial education.

These findings provide a reason to substantiate the particular training and capacity building needs of women entrepreneurs in the growth stage of their businesses.

\section{Methodology}

Training needs and preferences of women entrepreneurs were queried as part of a structured online questionnaire designed to determine the impact of women entrepreneurs' characteristics and capabilities on the growth and ultimate success of their businesses: education, training, issues hindering the growth process, factors contributing to growth, and prior experience.

The current research gathered both quantitative and qualitative information through a questionnaire containing a variety of scaled, open-ended, rank order, dichotomous, and multiple-choice questions, as well as some open questions inviting free response. The web-link of the online questionnaire was sent via email to 140 women entrepreneurs registered with the Centre for Women's Enterprise at the University of Bedfordshire. Also, a link to the web-based survey was put on the "Enterprising-Women" website. (Funded by the East of England Development Agency and the European Social Fund, this unique project is the brainchild of seven organisations that have come together to begin transforming support for women starting up a business and for those already trading and looking for growth. All the registered members of the programme were informed through email about the web-link.)

Initial data were collected through 108 on-line filled questionnaires followed by 15 telephone and 12 face-to-face in-depth interviews. Some of the advantages of adopting this online questionnaire methodology included reduced costs, increased response rate as compared to postal survey, shortened cycles of data collection, analysis and presentation, and enhanced interactivity of research materials (Stanton and Rogelberg, 2001). Statistical analysis using SPSS was applied to analyse the quantitative data; in addition, the qualitative data collected in response to open-ended questions were inductively analysed and interpreted.

Women entrepreneurs were asked about the number of trainings they had received in the previous two years, and the numbers of days per year spent on training activities to sustain and grow their businesses. Various training topics were surveyed for their usefulness, and respondents were asked to indicate from a list their three top priorities for training or to supply their own choices. Their interest in joining a training programme (either by CWE or by partner organisation at the Enterprising-Women project) was queried as well.

\section{Limitations of the methodology}

The survey sample was comprised of the mailing lists of the CWE and Enterprising-Women, plus those who accessed the Enterprising-Women website; this limited the survey's reach to women entrepreneurs mainly operating in service sectors as sole proprietors. Also geographic scope was limited to the East of England (Norfolk, Suffolk, Essex, Cambridgeshire, Hertfordshire, and Bedfordshire). However, according to the Global Entrepreneurship Monitor Report for 2004, (Minniti et al., 2005), the female Total Entrepreneurial Activity (TEA) in this region increased sharply

\section{Training needs for women- owned SMEs}

689 
ET

$50,8 / 9$

690 from 1.4 per cent to 3.5 per cent between 2002 and 2004 - which provides a reasonable base and a rationale for the study.

\section{Results and analysis \\ Demographics}

The distribution of the respondents confirmed previously published findings (Brush et al., 2004, Carter and Allen, 1997) that most women-owned enterprises operate in highly competitive service sectors. Almost 76 per cent of the respondents of this survey operate in service sectors, followed by trading (15.9 per cent) and manufacturing (8.4 per cent). Though, only 75 per cent confirm their status as owner and operating head, and almost one quarter consider themselves as "owner only", ninety eight per cent are responsible for making decisions regarding day-to-day affairs of their businesses in addition to making strategic decisions, which establishes their hold on the business even when they do not run things themselves.

Only 7 per cent of the businesses surveyed had been established for more than ten years. A large proportion of the respondents (71 per cent) established their businesses after 2001, which confirms the sharply rising trend in female TEA in the East of England between 2002 and 2004, as reported in the GEM report (Minniti et al., 2005).

Table I compares the status of business structure at start-up and at present. The results confirm previous findings in the literature (Forsyth, 2000; Rosa et al., 1996) that women entrepreneurs are most commonly self-employed sole proprietors in service sectors. In some cases, status changes with progression through the business life cycle. Table I shows a 9 per cent decline in sole proprietorships and an 11 per cent rise in the number of private limited companies. As firms grow, entrepreneurs prefer to register as private limited companies (Brush et al., 2005) because this form of business ownership offers limited liability to its owners as compared to the sole proprietorship where the liability is unlimited.

Only two companies out of the sample $(n=108)$ were able to progress to public limited status. The figure is quite comparable to overall business status figures of the UK economy. Partnerships with non-family members remained unchanged; however, one reason for a small decrease in number of partnerships with family members could be the change in spousal relationships. Two entities were registered as social enterprises and their status remained unchanged.

A total of 76 per cent of respondents had gained work experience in the same sector in which they opened their business; 42 per cent had one year of work experience, 37

\begin{tabular}{lcc}
\hline Types of establishment & $\begin{array}{c}\text { At start } \\
(\%)\end{array}$ & $\begin{array}{c}\text { At present } \\
(\%)\end{array}$ \\
\hline Sole proprietorship/sole trading & 64.81 & 56.48 \\
Partnership with family member(s) & 10.19 & 6.48 \\
Partnership with non-family member(s) & 4.63 & 4.63 \\
Private Limited Company & 18.52 & 28.70 \\
Public Limited Company & - & 1.85 \\
Charity/non-profit organisation & 1.85 & 1.85 \\
Other & - & -
\end{tabular}

Table I.

Other

Note: Base $=108$ 
per cent had two to five years - whereas 19 per cent had more than ten years prior to embarking upon their own enterprises. Only 41 per cent had attained any formal business education or training before starting their businesses.

\section{Assessment of motivation and training needs}

In order to design, develop, and conduct appropriate training in an effective and efficient manner, it is vital to have a complete understanding of what beneficiaries would like to achieve. Entrepreneurs' motivations, intentions and aspirations play a crucial role in the performance of their businesses and women's pursuit of different 'intrinsic' goals as compared to men's is a "compelling argument for anticipating gender differences in growth intentions” (Cliff, 1998, p. 527); see also (Brush et al., 2005, Forsyth, 2000). This study investigated the "push" and "pull" factors of motivations for women entrepreneurs to start their businesses so that their perceptions about training needs and preferences could be analysed in the light of their motivations, aspirations and intentions as well.

The two most important goals for the establishment of the respondents' businesses were to generate enough income to support themselves and their families, and to achieve enough balance between work, family responsibilities and other interests. These "push" factors were evident in their choice to seek training in the previous two years. Only 28 per cent received training on the topics related to the growth of their businesses while most of them (67 per cent) named building a successful enterprise as their first priority - possibly indicating some conflict between their two main goals that could be addressed by properly designed training programmes.

Apart from one respondent, who acquired a six month professional diploma in marketing, on average the respondents spent 3-5 working days per year attending training on different aspects of business growth. An analysis of their narrative responses reveals that most attended training on topics related to business start-up such as writing a business plan, time management, professional presence, telephone sales skills, inland revenue training, etc.

\section{Preference for training programmes}

One of the key objectives of this study was to know about the relative importance of different training programmes for women entrepreneurs. Respondents were asked to rank the usefulness of a number of training topics (on a scale of 1 to 5) in growing and sustaining their businesses over the next two years. All the carefully chosen topics related to personal, managerial and entrepreneurial skills were categorised into different business management functions such marketing and sales, human resource management, finance, and personal development. Table II shows their preferences for the usefulness of training programmes in descending order:

Training on innovation and opportunity recognition is considered to be one of the most useful capacity building activities (mean $=4.145$ ) to assist respondents in sustaining and growing their businesses. By ranking training on innovation and opportunity recognition as their highest priority, respondents confirm that most of them fulfill both Schumpeter's rather old definition of an entrepreneur as "the person who destroys the existing economic order by introducing new products and services, by creating new forms of organizations, or by exploiting new raw materials" (Schumpeter, 1951, p. 22) and a more recent definition of entrepreneurship as "the
Training needs for womenowned SMEs

691 
ET
$50,8 / 9$

\begin{tabular}{|c|c|c|c|}
\hline Topics & Mean & SD & $\begin{array}{c}\text { Standard error } \\
\text { of the mean }\end{array}$ \\
\hline Innovation and opportunity recognition & 4.145833 & 1.154513 & 0.117832 \\
\hline Business evaluation and growth considerations & 4.010204 & 1.025142 & 0.103555 \\
\hline Developing strategic customers and customer care & 3.918367 & 1.103551 & 0.111476 \\
\hline Selling skills & 3.767677 & 1.153197 & 0.115901 \\
\hline Customer relationship management & 3.714286 & 1.160577 & 0.117236 \\
\hline Marketing management & 3.603960 & 1.335570 & 0.132894 \\
\hline Networking skills & 3.525773 & 1.184894 & 0.120308 \\
\hline Negotiation skills & 3.494949 & 1.358652 & 0.136550 \\
\hline Finance raising/approaching investors & 3.453608 & 1.428867 & 0.145080 \\
\hline Decision making & 3.447917 & 1.257227 & 0.128315 \\
\hline Problem solving & 3.375000 & 1.268611 & 0.129477 \\
\hline Marketing research & 3.322917 & 1.432472 & 0.146201 \\
\hline Financial management and accounting & 3.303030 & 1.184535 & 0.119050 \\
\hline Brand management & 3.303030 & 1.403132 & 0.141020 \\
\hline Delegation and control & 3.136842 & 1.334644 & 0.136932 \\
\hline Managing difficult people & 3.113402 & 1.299296 & 0.131924 \\
\hline Pricing for profit & 2.979592 & 1.406832 & 0.142111 \\
\hline Time management & 2.979381 & 1.300114 & 0.132007 \\
\hline Leadership & 2.918367 & 1.352801 & 0.136654 \\
\hline IT for business promotion & 2.888889 & 1.569204 & 0.157711 \\
\hline IT skills for growth & 2.878788 & 1.545752 & 0.155354 \\
\hline Personal and professional presence & 2.835052 & 1.551058 & 0.157486 \\
\hline E marketing - web evaluation & 2.797980 & 1.645194 & 0.165348 \\
\hline Confidence building & 2.546392 & 1.492390 & 0.151529 \\
\hline Creativity and natural expression & 2.525773 & 1.268921 & 0.128839 \\
\hline Presentation skills & 2.464646 & 1.512995 & 0.152062 \\
\hline Communication skills & 2.438776 & 1.539058 & 0.155468 \\
\hline Assertiveness & 2.414141 & 1.428499 & 0.143570 \\
\hline Human resource management & 2.389474 & 1.145193 & 0.117494 \\
\hline Intellectual property rights & 2.336735 & 1.571064 & 0.158701 \\
\hline Body language & 2.272727 & 1.354515 & 0.136134 \\
\hline Team building & 2.260417 & 1.408640 & 0.143769 \\
\hline Quality control & 2.123711 & 1.437766 & 0.145983 \\
\hline Firm's social responsibility & 2.066667 & 1.339983 & 0.141247 \\
\hline Recruitment and interview techniques & 2.031250 & 1.158781 & 0.118268 \\
\hline Franchising & 1.906250 & 1.190922 & 0.121548 \\
\hline Production planning & 1.822917 & 1.298996 & 0.132578 \\
\hline Employment law for managers & 1.800000 & 1.310685 & 0.134473 \\
\hline
\end{tabular}

Table II.

Training programmes preference

Note: Base $=108$

pursuit of opportunity beyond the resources currently controlled" (Stevenson and Gumpert, 1985). This preference also explains the respondents' growth trend, because innovation and opportunity recognition are considered to be the foundations for exponential growth in entrepreneurial ventures (Burns, 2001). As product and technology life cycles are shortening, every product eventually becomes obsolete and requires a successor, an innovation. Customer demands and expectations remain an important driving force behind innovation; in order to satisfy this demand, companies must provide a continuous stream of new and improved products, processes and 
services (Janszen, 2000). The need to improve is in fact universal, irrespective of company or gender of the owner, and is evident in the results of this research study.

Developing strategic customers and customer care is ranked at number two $($ mean $=4.01)$ followed by selling skills (mean $=3.918)$, customer relationship management $($ mean $=3.767)$, and marketing management $($ mean $=3.603)$. These results verify the realisation by women entrepreneurs that attracting new customers and retaining them are prominent challenges for those interested in the growth and development of their businesses.

Studies confirm that firms grow through the use of their contacts and external relations and become competitive (Brush et al., 2004; Lechner and Dowling, 2003). A number of other researchers (Aldrich, 1989; Brush et al., 2004; Brush et al., 2005; Olm et al., 1988) have mentioned women's lower success at penetrating informal financial networks, which can lower their chances of generating appropriate, timely and sufficient resources. The women in this study considered lack of networking abilities and opportunities as a crucial barrier to business growth, despite the fact that there are many networking organisations for female entrepreneurs in their region. The same consideration is evident in the high preference expressed for training in networking $($ mean $=3.525)$ and negotiating $($ mean $=3.4949)$.

The demand for capacity building in raising finance and approaching investors (mean $=3.453$ ) endorses their concern about the non-availability or difficulty in accessing capital as one of the most critical factors hindering growth.

Churchill and Lewis (1983) indicate that problem-solving and decision-making capabilities of entrepreneurs are decisive in contributing to success. Women entrepreneurs expressed decision-making (mean $=3.4479$ ) and problem-solving (mean $=3.375$ ) as their next priorities for training. It is interesting that these ranked higher than financial management and accounting (mean $=3.303$ ) and brand management (3.303).

Many entrepreneurs expressed a shortage of skilled labour and high turnover as major barriers to growth. Quite surprisingly however, delegation and control $($ mean $=3.136)$, managing difficult people $($ mean $=3.113)$, leadership $($ mean $=2.918)$, team building (mean $=2.60)$, human resource management (mean $=2.389)$ and employment law for managers (mean $=1.8$ ) were ranked relatively low. One reason for this could be the bias in the dataset toward service sectors, where relatively small numbers of employees are common at initial stages of growth and expansion and such issues are less likely to be pressing. Again, a low number of respondents from manufacturing sectors (8.4 per cent) could be a reason for low expressed demand for training quality control (mean $=2.123$ ) and production planning (mean $=1.8229$ ), as well as intellectual property rights (mean $=2.3367$ ) and firm's social responsibility $($ mean $=2.066)$.

Despite their popularity at the pre-start-up and start-up stages, most of the "soft" skills such as personal and professional presence (mean $=2.835$ ), confidence building $($ mean $=2.546)$, communication skills $($ mean $=2.438)$, assertiveness (mean $=2.414)$, and body language (mean $=2.2727$ ) were ranked relatively lower. Current delivery of training on these topics by a number of existing providers could be a reason for low demand among respondents.

Despite its significant role in the growth of enterprises, training on franchising (mean $=1.906)$ is not in demand as well. The results confirm the findings of Dant et al.

\section{Training needs for women- owned SMEs}

693 
ET

$50,8 / 9$

694
(1996) that women are less likely to use a franchising route to business ownership as they are either not aware of or attracted to the franchising option because of their relative inexperience and historically lower exposure to franchising.

In their narrative responses to training preference questions, almost all respondents repeated the priorities indicated in the rest of questionnaire. Only a few mentioned that training programmes on credit control, cash flow management, market research, performance management, and pricing might assist them in achieving their goal of business development.

\section{Conclusion}

Most respondents in this survey named appropriate business training as very important contributing factors to growth. Though 41 per cent of the respondents had attained business training at the time of start-up, and twenty eight per cent attained training to grow their businesses in the previous two years, a strong majority felt the need for further training in order to be consistently strong at all business life cycle stages.

Lack of business management training facilities was also perceived as a major barrier to growth. One of the reasons for this could be the fact that the majority of respondents had not been formally trained in the skills needed to operate an enterprise professionally, as only forty one per cent had attained any formal business education or training before starting their businesses. This points to a need for the design and delivery of specific business and technical training programmes by national and regional institutions responsible for fostering the growth of women-owned businesses.

Priorities are expressed for training related to innovation and opportunity recognition, business evaluation and business growth considerations, developing strategic customer care, networking skills, marketing management, selling skills and negotiation skills. These findings confirm that women entrepreneurs are interested in growing their enterprises, and are aware that the aptitude for innovation is nothing less than a direct reflection of an organisation's ability to change, to adapt to new and competent competitors, and to suit its products and services to the ever-evolving needs of customers (Burns, 2001).

\section{References}

Aldrich, H. (1989), "Networking among women entrepreneurs", in Hagan, O. and Sexton, C.R.D. (Eds), Women-owned Businesses, Praeger, New York, NY.

Bridge, S., O' Neil, K. and Cromie, S. (1998), Understanding Enterprise, Entrepreneurship and Small Business, Macmillan Business, London.

Brown, S., Doyle, W., Lewis, H., Mallette, D. and Young, P. (2002), Women Entrepreneurs in Canada in the 90's, Business Development Bank of Canada, Montreal.

Brush, C. and Hisrich, R. (1999), Women-Owned Businesses: Why Do They Matter?, Kluwer Academic Publisher, Boston, MA.

Brush, C. and Hisrich, R. (2002), Women-owned Businesses: An Exploratory Study Comparing Factors Affecting Performance, Research Institute for Small and Emerging Business Inc., Washington, DC.

Brush, C., Carter, M.N., Gatewood, J.E., Greene, G.P. and Hart, M. (2004), Clearing the Hurdles: Women Building High Growth Businesses, Financial Times - Prentice Hall, London. 
Brush, C., Carter, N., Gatewood, E. and Hart, M. (2005), The Diana International Report: Research on Growth Oriented Women Entrepreneurs and their Businesses, ESBRI, Stockholm.

Burns, P. (2001), Entrepreneurship and Small Business, Palgrave, Basingstoke.

Carter, N.M. and Allen, K.R. (1997), "Size determinants of women-owned business: choice or barriers to resources”, Entrepreneurship and Regional Development, Vol. 9 No. 3, pp. 211-20.

Chrisman, J., McMullen, E. and Hall, J. (2005), "The influence of guided preparation on the long-term performance of new ventures", Journal of New Business Ventures, Vol. 20 No. 5, pp. 769-91.

Churchill, N. and Lewis, V.L. (1983), "The five stages of small business growth", Harvard Business Review., Vol. 61 No. 3, pp. 30-50.

Cliff, J.E. (1998), "Does one size fit all? Exploring the relationship between attitudes towards growth, gender, and business size”, Journal of Business Venturing, Vol. 13 No. 6, pp. 523-42.

Dant, R.P., Brush, C. and Iniesta, F.P. (1996), "Participating patterns of women in franchising", Journal of Small Business Management, Vol. 34 No. 2, pp. 14-28.

Deakins, D. (1996), Entrepreneurship and Small Firms, McGraw Hill Companies, London.

Forsyth, F. (2000), “Women's enterprise and business development: lessons from targeted women's programmes in Glasgow”, Local Economy, Vol. 15 No. 1, pp. 18-31.

Gorman, G., Hanlon, D. and King, W. (1997), "Some research perspectives on entrepreneurship education, enterprise education and education for small business management: a ten year literature review”, International Small Business Journal, Vol. 15 No. 3, pp. 56-78.

Heilbrunn, S. (2004), "Impact of gender on difficulties faced by entrepreneurs", International Journal of Entrepreneurship and Innovation, Vol. 5 No. 3, pp. 159-65.

Henry, C., Hill, F. and Leitch, C. (2005), "Entrepreneurship education and training: can entrepreneurship be taught?", Journal of Education and Training, Vol. 47 No. 2, pp. 98-111.

Janszen, F. (2000), The Age of Innovation: Making Business Creativity a Competence, Not a Coincidence, Financial Times - Prentice Hall, London.

Lechner, C. and Dowling, M. (2003), "Firm networks: external relationships as source for the growth and competitiveness of entrepreneurial firms", Entrepreneurship and Regional Development, Vol. 15, pp. 1-26.

McMullan, E. and Long, W. (1987), "Entrepreneurship education in the nineties", Journal of Business Venturing, Vol. 2 No. 3, pp. 261-75.

Minniti, M., Arenius, P. and Langowitz, N. (2005), 2004 Report on Women and Entrepreneurship, Babson College and London Business School, Wellesley, MA and London.

O'Gorman, C. (1997), Success Strategies in High Growth Small and Medium Sized Enterprises, Macmillan, Basingstoke.

Olm, K., Carsrud, L. and Alvey, L. (1988), The Role of Networks in New Venture Funding for the Female Entrepreneur: A Continuing Analysis, Babson College, Wellesley, MA.

Park, S. and Bae, Z.T. (2004), "New venture strategies in a developing country: identifying a typology and examining growth patterns through case studies", Journal of Business Venturing, Vol. 19 No. 1, pp. 81-105.

Rosa, P., Carter, S. and Hamilton, D. (1996), "Gender as a determinant of small business performance: Insights from a British study”, Small Business Economics, Vol. 8, pp. 463-78.

Schumpeter, J. (1951), Essays: on Entrepreneurs, Innovations, Business Cycles, and the Evolution of Capitalism, Addison-Wesley, Cambridge, MA.

\section{Training needs for women- owned SMEs}

695 
ET

$50,8 / 9$

696

Singh, V. and Vinnicombe, S. (2003), "Women-only management training: an essential part of women's leadership development”, Journal of Change Management, Vol. 3 No. 4, pp. 294-306.

Smallbone, D., Leigh, R. and North, D. (1995), "The characteristics and strategies of high growth SMEs", International Journal of Entrepreneurial Behaviour and Research, Vol. 1 No. 3, pp. 44-62.

Stanton, J. and Rogelberg, S.G. (2001), "Using the internet/intranet web pages to collect organizational research data”, Organizational Research Methods, Vol. 4 No. 3, pp. 199-216.

Stevenson, H. and Gumpert, D. (1985), "The heart of entrepreneurship”, Harvard Business Review, Vol. 63 No. 2, pp. 85-94.

Storey, D.J. (1994), Understanding the Small Business Sector, Routledge, London.

van der Sijde, P., Van Tilburg, J., Henry, C., Sygne, J. and Asplund, R. (1997), UNISPIN Workbook, University of Twente, Twente.

\section{About the authors}

Muhammad Azam Roomi is a Senior Lecturer and the Director of Research at the University of Bedfordshire's Centre for Women's Enterprise. His research interests are in the growth and performance of SMEs, role of social capital and human capital in enterprise development, and women's entrepreneurship in the UK as well as Islamic and Asian countries. Muhammad Azam Roomi is the corresponding author and can be contacted at: Muhammad.roomi@beds.ac.uk

Pegram Harrison is the director of the London Business School's Emerging Leaders Programme. His research interests are in entrepreneurship education, social entrepreneurship and regional development.

To purchase reprints of this article please e-mail: reprints@emeraldinsight.com Or visit our web site for further details: www.emeraldinsight.com/reprints 